\title{
Polarity, expression of degree and negation: the vernacular form caraças
}

\section{Polaridade, expressão de grau e negação: a forma vernácula caraças}

\author{
Clara Pinto \\ Centro de Linguística da Universidade de Lisboa (Portugal) \\ clara.pinto@campus.ul.pt
}

Enviado: 17/10/2019

Aceptado: 19/03/2020

\begin{abstract}
This paper presents the vernacular form caraças which, in European Portuguese (EP) is associated to multiple contexts, different from its use as a feminine common noun. The data I will present shows that caraças behaves as a polarity item, without referential interpretation. On the one hand, caraças behaves as a minimizer, a subtype of Negative Polarity Item (NPI), being associated to the lowest point of a scale of value. On the other hand, it also behaves as a Positive Polarity Item (PPI), expressing maximal degree, therefore being a maximizer. The fact that caraças occurs simultaneously as a NPI and a PPI could indicate we are in the presence of a bipolar element, as described by van der Wouden (1997). Nevertheless, data suggests that there are two distinct items caraças, one of them being a NPI and the other a PPI.

The form caraças is also associated to other contexts of use, namely as a metalinguistic negation marker and in evaluative constructions such as $\mathrm{N}$-of-an- $\mathrm{N}$ constructions. We also find it functioning as an interjection in exclamative sentences.

Although the feminine common noun caraça (augmentative of cara 'face') remains in the lexicon as synonym of mask, the polarity item caraças does not result from a process of grammaticalization of the common noun, as documented for other polarity items. In this paper I will put forth the idea that caraças, in its masculine singular form, appeared as an euphemistic variant of caralho 'dick', a highly offensive taboo term, used to designate the masculine sexual organ
\end{abstract}

\section{Keywords}

polarity items; taboo terms; degree; negation

\section{Contents}

1. Introduction. 2. The common noun caraça and the form caraças. 3. Caraças as a polarity item. 4. A bipolar item or two different items? 5. Other uses of caraças. 6. The origin of the non-nominal uses of caraças. 7. Conclusion.

\section{Resumo}

Neste artigo é apresentada a forma vernácula caraças, que, em Português Europeu (PE), surge associada a múltiplos contextos, distintos do seu uso enquanto nome comum feminino. Os dados que serão apresentados mostram que caraças se comporta como um item de polaridade, desprovido de interpretação referencial. Por um lado, caraças apresenta-se como um Item de Polaridade Negativa (IPN), sendo empregue como minimizador, ou seja, associado ao menor ponto de uma escala de valor. Por outro, surge igualmente como Item de Polaridade Positiva (IPP), estando associado à expressão de um grau máximo. A possibilidade de caraças surgir, simultaneamente, como minimizador (IPN) e maximizador (IPP) poderia indicar que se trata de um elemento bipolar (nos termos de van der Wouden 1997). No entanto, a conclusão a que se chega é a de que existem dois itens caraças distintos, um deles correspondendo a um IPN e outro a um IPP.

A forma caraças surge ainda associada a outros usos, nomeadamente como marcador de negaçáo metalinguística e em construçóes de caráter avaliativo, tais como as chamadas construçóes $\mathrm{N}$-de- $\mathrm{N}$, e também com valor de interjeiçáo em frases exclamativas.

Embora o nome comum feminino caraça (aumentativo de $c a r a)$ permaneça no léxico e possa ser usado para designar um tipo de máscara, o item de polaridade caraças não parece ser o produto de um processo de gramaticalizaçáo a partir do nome comum, como acontece com outros itens de polaridade. Propóe-se que caraças, empregue no masculino, singular, terá antes surgido como eufemismo de caralho, termo tabu, considerado grosseiro e ofensivo, usado para designar o membro sexual masculino.

\section{Palavras-chave}

itens de polaridade; termos tabu; grau; negação

\section{Sumario}

1. Introdução. 2. O nome comum caraça e a forma caraças. 3. Caraças como item de polaridade. 4. Um item bipolar ou dois itens distintos? 5. Outros usos de caraças. 6. A origem dos usos não-nominais de caraças. 7. Conclusão. 


\section{Introduction}

CCORDing to Israel (2001), words denoting minimal degrees are usually used as Inegative polarity items (NPIs), while words denoting maximal degrees give rise to positive polarity items (PPIs). It is, therefore, unexpected that one same item can be used both as a PPI and a NPI, expressing minimal and maximal degree, simultaneously. This is, apparently, the case of the European Portuguese (EP) item caraças.

In this paper I will investigate the item caraças, which is used in EP both as a PPI and a NPI and I will try to understand whether we are in the presence of a single item with mixed behavior or, alternatively, two independent items with the same lexical form. I will also show that the form caraças is associated to other contexts of use, such as evaluative constructions, as an interjection and associated to metalinguistic negation (Horn 1989). Finally, I will put forth a possible explanation for the emergence of caraças, in its multiple uses in colloquial language, as a replacement for another item considered offensive, i.e. caralho (slang word for 'penis').

\section{The common noun caraça and the form caraças}

In Portuguese, the word caraça is dictionarized as a feminine common noun meaning 'mask'. It is also registered as being the augmentative form of the noun cara 'face' and it can be used depreciatively to refer to an ugly face. Below we reproduce the corresponding lexical entry:

\section{Caraça. s. f.}

Máscara de papelão; carranca 2. Fig. Cara larga e cheia: "era um figurão baixo, reboludo, de pancinha soprada, caraça balofa com manchas vermelhas" (José Gomes Ferreira, O Mundo dos Outros, pág. 177) 3. V. carantonha. •S. m. 4. Boi ou cavalo com malha branca no focinho. ${ }^{1}$

(Ferreira 1986: 346)

Its use as a common noun can be tracked back as early as the 17 th century ${ }^{2}$, as illustrated in (1), where it appears with the meaning of mask, and (2), where it is used to refer to an unattractive face.

1. Caraça. s. f.: Cardboard mask; frown 2. Fig. Large and full face. 3. See ugly face. 4. Ox or horse with a white stain in the nose.

2. The Dicionário Houaiss da Lingua Portuguesa indicates a much later date for the first attestation, namely 1771 . 
(1) E afirmo a VM que me não parecem isto biocos nem and state. ${ }_{1 \mathrm{SG}}$ to you that me. ${ }_{\text {Dat }}$ neg seem. ${ }_{3 \mathrm{PL}}$ this veils nor caraças, mas que hão de ser obras. masks but that will. $_{3 \mathrm{PL}}$ be deeds

'And I tell you that this do not look like veils nor masks to me but they must be deeds.'

(Post Scriptum, PSCR1418, 1600-1603)

$\begin{array}{llllllllll}\text { (2) } & \text { Brites: } & \text { Se } & \text { da } & \text { minha } & \text { fermusura/ } & \text { tu } & \text { tens } & \text { raiva, minha } \\ \text { Brites: } & \text { If } & \text { of.the } & \text { my } & \text { beauty/ } & \text { you } & \text { have } & \text { rage, } & \text { my } & \\ \text { Páscoa,/ } & \text { tem } & \text { pasciência, } & \text { que } & \text { assim } & \text { como } & \text { eu } & \text { sou } & \text { tão } & \\ \text { Easter } & \text { have. }_{2 S G} & \text { patience, } & \text { that } & \text { like.this } & \text { as } & \text { I } & \text { am } & \text { so } & \\ \text { fermosa } & \text { o } & \text { poderias } & \text { ser } & \text { tu/ } & \text { e } & \text { eu } & \text { ter } & \text { essa } & \text { caraça. } \\ \text { beautiful } & \text { it } & \text { could } & \text { be } & \text { you/ } & \text { and } & \text { I } & \text { have } & \text { that mask }\end{array}$

'Brites: If my beauty makes you angry, my dear, be patient, because, just like I am beautiful, you could be too and I could have that ugly face instead.'

(Teatro de autores portugueses do Séc. XVII - Base de datos textual: Anónimo, O Pai Ambrósio)

In both examples, caraça is a common noun and displays feminine gender. In (1) it appears in its plural form, while in (2) it is singular. Contemporary examples such as (3) and (4) illustrate, however, a use of the form caraças which is different from the ones presented before. In both cases the interpretation of the item does not correspond to any of the meanings listed in the dictionary entry above ${ }^{3}$.

$\begin{array}{llllll}\text { (3) Aquilo demonstra } & \text { uma preparação física } & \text { do } & \text { caraças. } \\ \text { that } & \text { Shows. }_{3 \mathrm{sg}} & \text { a } & \text { preparation } & \text { physical } & \text { of.the. } \\ \text { MASC.SG } & \text { caraças }\end{array}$

'That reveals a hell of a physical preparation.'

(Corpus CetemPublico, par=ext1066477-clt-92a-2)

$\begin{array}{ccccccc}\text { (4) «Teste amanhã } & \text { e } & \text { ainda } & \text { náo } & \text { estudei } & \text { um } & \text { caraças.» } \\ \text { test } & \text { tomorrow and } & \text { yet } & \text { neg } & \text { studied } & \text { a. }{ }_{\text {MASC.SG }} & \text { caraças }\end{array}$

'Test tomorrow and I have not studied a thing yet.'

(Twitter, 21/05/2018)

3. Since there is absolutely no relation between the item caraças and the common noun caraça in terms of meaning, and, therefore, there is no translation available, I have decided to use the form of the item itself in the glosses. Whenever we are in the presence of the common noun the gloss will be "mask". 
The first piece of evidence that clearly shows that caraças in (3) and (4) does not correspond to the plural form of the common noun caraça is the lack of referential meaning. None of the sentences admits a referential reading of the item, as we conclude by the awkwardness of sentences (5) and (6) in which the item caraças was replaced by the synonym common noun máscara 'mask'.

\begin{tabular}{|c|c|c|c|c|c|}
\hline \#Aquilo & demonstra & uma & preparação & física & da \\
\hline that & Shows. $_{3 \mathrm{SG}}$ & $\mathrm{a}$ & preparation & physical & of.the \\
\hline
\end{tabular}

'That reveals a physical preparation of the mask'

\begin{tabular}{|c|c|c|c|c|c|c|}
\hline \#Teste & amanhã & e & ainda & não & estudei & uma \\
\hline test & & and & & neg & studied. & $\mathrm{a}$ \\
\hline
\end{tabular}

'Test tomorrow and I have not studied a mask.'

The presence of máscara in (5) and (6) produces a sentence with a different interpretation from the ones in (3) and (4). Aditionally, in example (4), the reading of um caraças as a Direct Object (DO) of the verb estudar 'study' is optional, while in (6), when interpreted as synonym of máscara 'mask', it is mandatory. Sentence (4) corresponds to a context of optionally transitive verb, allowing for the interpretation of um caraças as a DO or as a negation reinforcement particle (about optionally transitive verbs and negation see Willis 2010, 2012; Parry 2013, a.o.), this last reading not being available for the common noun máscara.

A second observation that indicates that caraças is independent from the common noun is related to its $\theta$-features. While in (1) and (2) the common noun caraça displays feminine morphology and it agrees with the feminine possessive determiner essa 'that' in (2), that is not the case in examples (3) and (4). Here we find caraças occurring with the definite determiner $o$ 'the', as in (3), and with the indefinite determiner $u m$ ' 'a', as in (4), both in the masculine. The replacement of the masculine determiners by their feminine counterparts would render the sentences ungrammatical, as we can see in (7), where we find the feminine definite determiner $a$ 'the' and in (8), with de indefinite feminine determiner uma 'a':

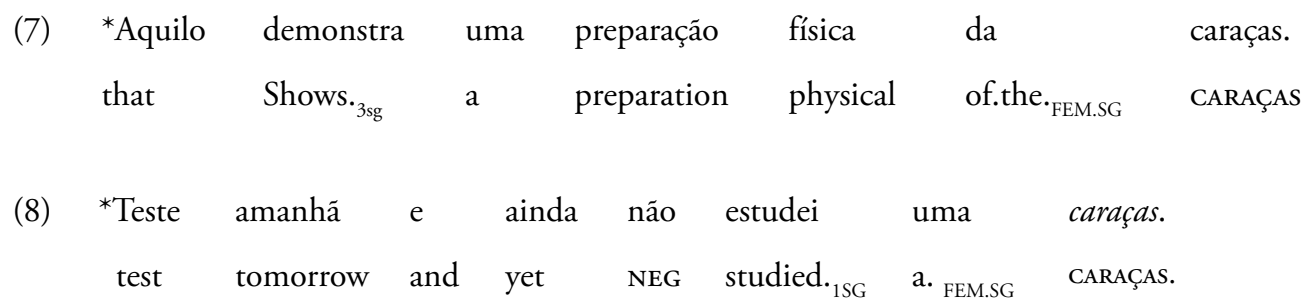


Similarly, both sentences (3) and (4) present an apparent plural form of the noun caraça due to the presence of the final $<s>$. Nevertheless, there is no number agreement between the item and the determiners preceding it, since both determiners occur in the singular. Once again, replacing the singular determiners by their plural counterparts would render the sentences ungrammatical, as illustrated in (9) and (10). This indicates that caraças displays plural morphology (visible in the final $<s>$ ) but singular number.

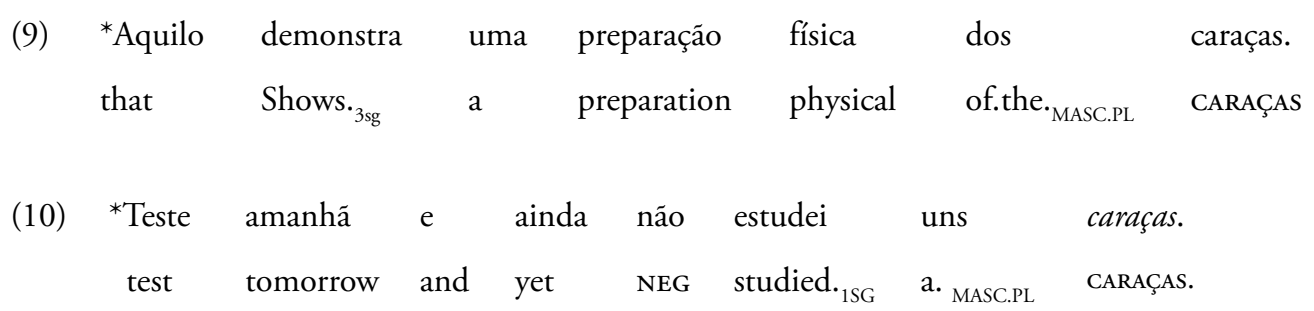

In fact, caraças in (3) and (4) is neutral as far as gender and number are concerned (there is singular masculine agreement by default), precisely due to its non-nominal nature ${ }^{4}$.

At this point, it can be stated that the contemporary use of caraças illustrated in (3) and (4) does not correspond to the common noun caraça but it is actually a polarity item. Later on, in section 6, I will discuss the etymology of caraças, whose origin will become clear after its behavior as a polarity item (and associated uses) is thoroughly described.

\section{Caraças as a polarity item}

As we have seen in the previous section, there seems to be two different items with the form $\operatorname{caraça}(s)$ : one which is a common noun and another which is not. In the present section I will try to show that the non-nominal item caraças is actually a polarity item.

Languages display certain lexical items that can only appear in environments associated with a particular grammatical polarity: these items are known as polarity items and are usually divided into positive polarity items (PPI) and negative polarity items (NPI) ${ }^{5}$. Following Giannakidou (2011:74), "AFFIRMATIVE PIS,

4. There are some NPIs that alternate between a form with a similar final $<$ s $>$ and another without it. One example of this alternation is the NPI népia, which can also occur under the form népias, which does not correspond to a plural form.

5. A third category needs also to be considered - modal polarity items (MPI's) - in the sense of Bosque (1996). Some authors also recognize the existence of bipolar items (cf. van der Wouden 1997 and Spector 2012). 
or POSITIVE PIS (PPIS) are expressions that are 'repelled' by negation and tend to escape its scope". On the other hand, according to Horn (1989: 49), NPIs are "expressions which can only appear felicitously within the scope of negation (or a semantically related operator)".

Examples from (11) to (13) present the common noun caraça and the polarity item caraças in three sentences with different polarity: affirmative assertive, modal and negative, accordingly.

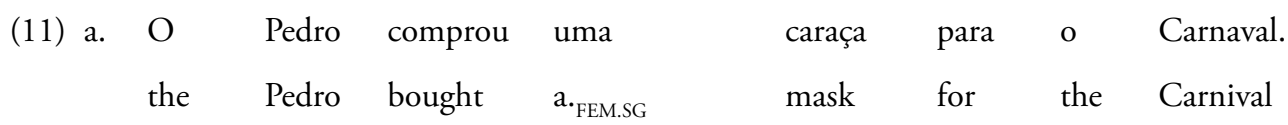
'Pedro bought a mask for Carnival.'
b. Este livro é caraças.
this book is of.the. MASC.SG CARAÇAS

'This book is awesome.'

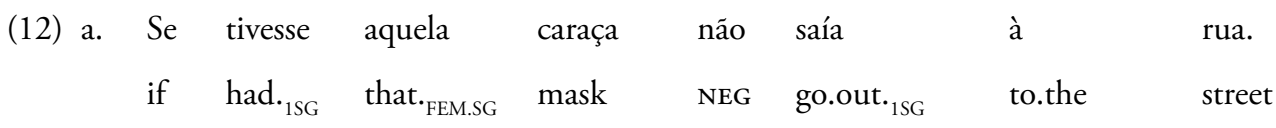
'If I had that face, I would not go out on the street.'
b. Se fizesses um
caraças não estarias aborrecido.
CARAÇAS NEG
would.be. $_{25 \mathrm{G}}$ bored
if $\operatorname{did}_{\text {2SG }} \quad$ a. $_{\text {MASC.SG }}$

'If you did anything, you would not be bored.'

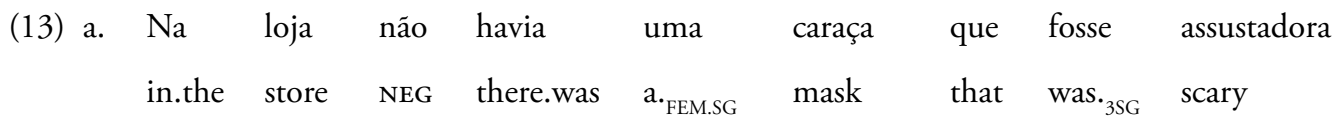
'There was not one scary mask at the store.'
b. Este livro não vale um caraças.
this book NEG be.worth a. ${ }_{\text {MASC.SG }}$ CARAÇAS

'This book is not worth anything.'

As it becomes clear from the comparison between the sentences in $a$. and $b$. from (11) to (13), only the common noun in $a$. maintains the referential meaning of mask or ugly face, regardless of the sentence in which it occurs. On the other hand, caraças as a polarity item in $b$. acquires different meaning depending on the polar context in which it occurs. In an affirmative assertive sentence such as (11b), caraças has positive interpretation, expressing a very positive evaluation of the book. Its presence in the sentence can be considered equivalent to saying that the book was very good. When in 
the scope of a modal operator, such as in (12b), where it occurs within a conditional clause, caraças is a NPI with positive reading (existential reading), equivalent to an$y$ thing. Finally in (13b) it appears in the scope of the negative operator não and has negative interpretation, similar to nothing.

A closer observation of the sentences in $b$., with the polarity item caraças, makes clear that the item has scalar properties. In the affirmative sentence (11b), caraças actually expresses a maximal degree. Saying that the film was do caraças is equivalent to saying that it was good in a very high degree ${ }^{6}$. On the other hand, in (13b) caraças is used to reinforce a negative degree. If one says that the film was not worth um caraças that means it was not worth the most minimal amount, and, therefore, it is worthless. In (11b) we find caraças being used as a maximizer, while in (13) it is a minimizer. I will consider that maximizers are a subtype of Positive Polarity Items (PPI) that refer to maximal degrees, while minimizers are a subtype of Negative Polarity Items (NPI) which refer to minimal units of size or value (cf. Hoeksema 2001).

The fact that, apparently, caraças can occur in sentences with affirmative, modal and negative polarity brings an issue to the discussion. As stated before, PPIs are repelled by negation, the same way NPIs are not possible in affirmative assertive sentences. How is it, then, that the item caraças is legitimated in both contexts, presenting itself simultaneously as a PPI and a NPI? Two possibilities arise: one is to consider that caraças is what van der Wouden (1997) called a bipolar element, the other is to assume that there are two items caraças (apart from the common noun caraça), one being a PPI and another a NPI. Nevertheless, before addressing this question, let us take a brief look at the internal structure of the maximizer and minimizer expressions that include caraças, since this will prove relevant to determine its classification as a single polarity item or, instead, two distinct polarity items.

When we look at example (11b) on the one hand, and examples (12b) and (13b), on the other, we realize there is a difference regarding the internal structure of the polarity expressions. In ( $11 \mathrm{~b}$ ), where caraças is a maximizer (and, therefore, a PPI), it appears as the nominal head of a definite Determiner Phrase (DP) which is, by its

6. An anonymous reviewer draws attention to the fact that the evaluation conveyed by caraças may not be positive at all times. In fact, the function of caraças as a PPI is to express maximal degree, and this can be associated to a negative evaluation, as in example (i). Nevertheless, the possibility of emphasizing a negative characteristic does not affect its PPI status.

\begin{tabular}{|c|c|c|c|c|c|c|}
\hline Apenas & a & vizinha & do & $5 .^{\circ}$ & andar & é \\
\hline Only & the & neighbour & of.the & fifth & floor & is \\
\hline chata & do & caraças & & & & \\
\hline boring & of.the. ${ }_{\text {MASC.SG }}$ & CARAÇAS & & & & \\
\hline
\end{tabular}


turn, the complement of a Prepositional Phrase (PP) introduced by the preposition de 'of' (do caraças). A different scenario is observed in examples (12b) and (13b) where caraças is a minimizer (and, therefore, a NPI) and appears as a nominal head of an indefinite DP (um caraças) ${ }^{7}$. The relevant fact here is that the minimizer cannot occur as the DP complement of a PP but the maximizer must occur in this configuration. Examples from (14) to (16) illustrate these restrictions.

a. $\quad[P P d$ [DP o caraças $]]$

$$
\begin{aligned}
& \text { Este livro é [PP of [DP the. } \left.{ }_{\text {Def.MASC.SG }} \text { CARAÇAS }\right] \\
& \text { this book is b. *[DP o caraças }] \\
& \text { [DP the. }{ }_{\text {Def.MASC.SG }} \text { CARAÇAS] } \\
& \text { c. * } \quad \text { [DP um caraças }] \\
& \text { [DP a. } \text { Indef.MASC.SG }_{\text {CARAÇAS] }}
\end{aligned}
$$

$$
\begin{aligned}
& \text { a. [DP um caraças] } \\
& \text { [DP a. } \text { Indef-MASC.SG }_{\text {CARAÇAS] }} \\
& \text { Se fizesses b. *[PP d [DP o caraças] não estarias aborrecido } \\
& \text { if } \left.\left.\text { did. }_{2 S G} \quad \text { [PP of [DP the. }{ }_{\text {Def-MASC.SG }} \text { CARAÇAS }\right]\right] \text { NEG would.be. }{ }_{2 S G} \text { bored } \\
& \text { c. } *[\mathrm{DP} \text { o caraças }] \\
& \text { [DP the. }{ }_{\text {Def-MASC.SG }} \text { CARAÇAS] }
\end{aligned}
$$

$$
\begin{aligned}
& \text { a. [DP um caraças] } \\
& \text { [DP a. }{ }_{\text {Indef-MASC.SG }} \text { CARAÇAS] } \\
& \text { Este livro não vale } \\
& \text { b. *[PP d [DP o caraças] } \\
& \text { this book NEG be.worth } \\
& \text { [PP of [DP the. } \text { Def.MASC.SG }_{\text {CARAÇAS] }} \\
& \text { c. *[DP o caraças }] \\
& \text { [DP the. }{ }_{\text {Def.Masc.SG }} \text { CARAÇAS] }
\end{aligned}
$$

The ungrammaticality of the examples in $b$. and $c$. clearly shows that the PPI maximizer must assume the form $(d) o$ caraças and appear as the complement of a PP. On the other hand, the NPI minimizer is always the indefinite DP um caraças.

7. For the intended discussion of the data it is not crucial to elaborate on a more fine-grained internal structure of the DP containing the item caraças. For sake of simplicity we will also refer to um and $o$ in um caraças and $o$ caraças as corresponding to the definite and the indefinite determiners, respectively. Nevertheless, the classification of $u m$ as a cardinal number (cf. Tubau 2016) is not discarded by our option. 


\section{A bipolar item or two different items?}

The term bipolar element was used by van der Wouden (1997) to classify items that display mixed behavior between PPIs and NPIs. The author considers that a bipolar element is a negative polarity item (of the weakest type) which is only licensed in a monotone decreasing context and in antimorphic contexts. On the other hand, it is a (weak) positive polarity item in causing ungrammaticality in antimorphic contexts, that is to say, under the scope of direct negation.

According to van der Wounden (1997) a bipolar item may occur in a monotone decreasing (downward entailing) context. Monotone decreasing contexts allow inferences from a set to a subset, as illustrated in (17) with do caraças and (18) with um caraças.

$$
\begin{array}{llllllll}
\text { a. Duvido que o } & \text { Luís tenha } & \text { comprado } & \text { um } & \text { livro. } \\
\text { doubt. }_{1 S G} & \text { that } & \text { the } & \text { Luís } & \text { has } & \text { bought } & \text { a } & \text { book }
\end{array}
$$

'I doubt Luís has bought a book.

$\begin{array}{llllllllll}\text { b. Duvido } & \text { que } & \text { o } & \text { Luís } & \text { tenha } & \text { comprado } & \text { um } & \text { livro } & \text { do } & \text { caraças } \\ \text { doubt. }_{1 S G} & \text { that } & \text { the } & \text { Luís } & \text { has } & \text { bought } & \text { a } & \text { book } & \text { of.the. }_{\text {MASC.SG }} & \text { CARAÇAS }\end{array}$

'I doubt Luís has bought and awesome book.'

\begin{tabular}{|c|c|c|c|c|c|c|c|}
\hline a. Duvido & que & o & Luís & tenha & dormido. & & \\
\hline doubt. $_{1 S G}$ & that & the & Luís & has & slept & & \\
\hline \multicolumn{8}{|c|}{ 'I doubt Luís has slept.' } \\
\hline b. Duvido & que & o & Luís & tenha & dormido & um & caraças. \\
\hline doubt. $_{15 G}$ & that & the & Luís & has & slept & $\mathrm{a}_{\text {MASC.SG }}$ & CARAÇAS \\
\hline
\end{tabular}

In both cases, we can infer that, if what is stated in the first sentence (sentence a.) is true, then the proposition of the second sentence (sentence b.) is also true. Nevertheless, if we reverse the order of the sentences, creating a monotone increasing context (or upward entailing), only the pair in (18) can be inferred. In (18), if I say that Luís did not sleep, it is implicit that he did not sleep a thing. On the other hand, if Luís did not sleep a thing, it is also true that he did not sleep. However, the same logic does not apply in (17). If I doubt that Luís bought a book, it is true that I also doubt that he bought an awesome book. But if I doubt that he bought an awesome book, one cannot infer that I doubt he bought a book (I may believe that he bought a very bad book). 
Additionally, bipolar items are said to be ruled out from antimorphic contexts, under the scope of direct negation. Compare examples (19) and (20).

$\begin{array}{lccccccc}\text { \#O } & \text { CR7 } & \text { não } & \text { é } & \text { um } & \text { jogador } & \text { do } & \text { caraças. } \\ \text { the } & \text { CR7 } & \text { NEG } & \text { is } & \text { a } & \text { player } & \text { of.the. }_{\text {MASC.SG }} & \text { CARAÇAS } \\ \text { 'CR7 is not an awesome player.' } & & & \end{array}$

$\begin{array}{llllll}\text { O } & \text { CR7 } & \text { não } & \text { joga } & \text { um } & \text { caraças. } \\ \text { the } & \text { CR7 } & \text { NEG } & \text { is } & { }^{a}{ }_{\text {MASC.SG }} & \text { CARAÇAS }\end{array}$

'CR7 does not play a thing.'

While the scope of negation is the most frequent licensing context for um caraças, and, therefore, the sentence is grammatical, the occurrence of do caraças in the direct scope of a negative operator renders the sentence unnatural. These contrasts clearly indicate that um caraças behaves like a NPI, while do caraças behaves like a PPI. Further evidence is given in examples (21) to (23).

The observation of examples below shows that the two polarity expressions including caraças cannot occur in the same contexts. In (21) the PPI, but not the NPI, can occur in affirmative assertive sentences, while only the NPI is adequate in a negative context like (22). They are both possible in a modal context such as (23), in the protasis of a conditional sentence, since both PPIs and weak NPIs are legitimated in such environments.

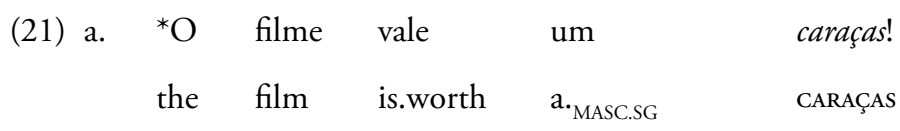

'The film is worth a thing'. (minimizer reading intended)

b. O filme é do caraças!

the film is of.the. .MASC.SG CARAÇAS

'The film is awesome.'

$\begin{array}{llllll}\text { (22) a. } \mathrm{O} & \text { filme } & \text { não } & \text { vale } & \text { um } & \text { caraças! } \\ & \text { the film } & \text { NEG } & \text { is.worth } & \text { a. }{ }_{\text {MASC.SG }} & \text { CARAÇAS }\end{array}$

'The film is not worth a thing.'

b. \#O filme não é do caraças!

the film NEG is of.the. ${ }_{\text {MASC.SG CARAÇAS }}$

'The film is not awesome' 


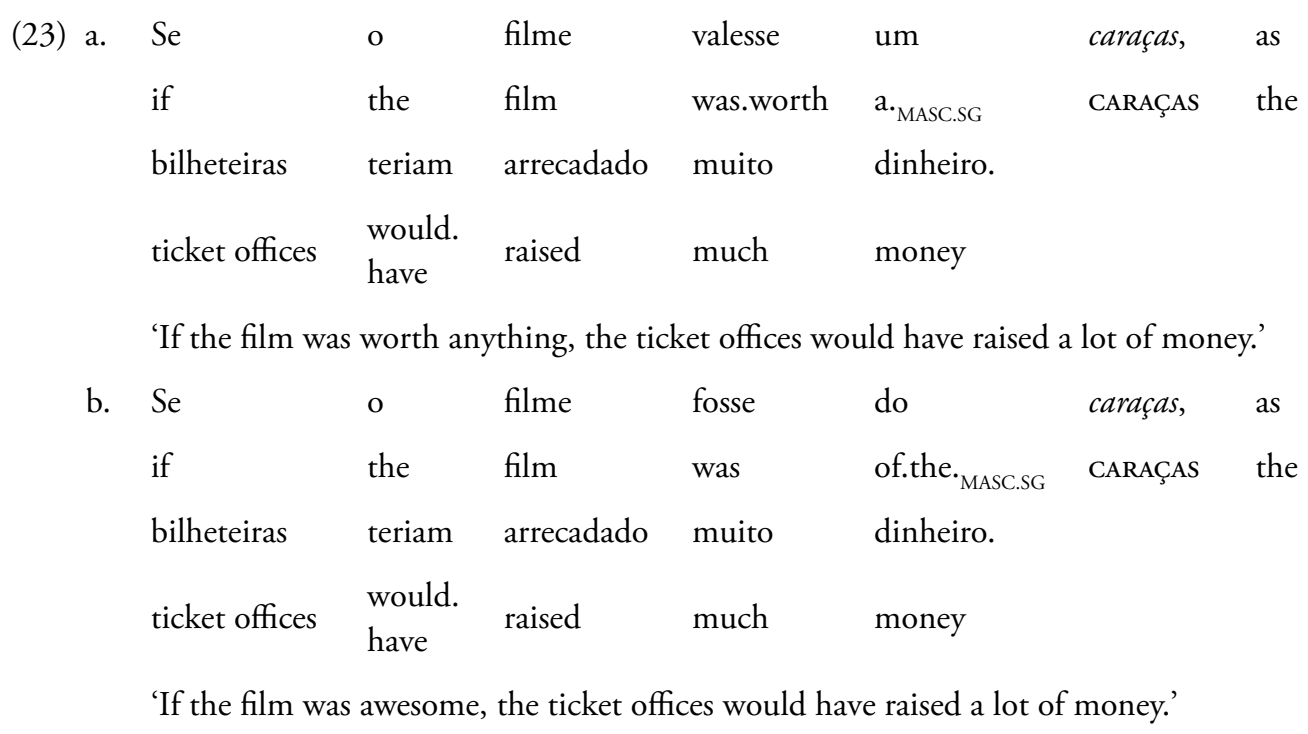

Another argument in favor of the existence of two different items sharing the same form is illustrated by metalinguistic negation contexts. Metalinguistic negation (Horn 1989) is a type of negation which depends on a specific discursive context and does not imply the truth or falsity of the propositions being denied. It is based on the notion of assertability of an utterance and, therefore, it does not constitute an instance of logical negation. In negative concord languages, such as Portuguese, metalinguistic negation does not trigger negative concord phenomena, therefore being incompatible with NPIs, but licensing PPIs under its scope. Examples (24) and (25) below illustrate the compatibility or incompatibility of the NPI um caraças and the PPI (d) $o$ caraças in metalinguistic negation contexts.

As mentioned before, metalinguistic negation differs from regular negation. Most instances of metalinguistic negation are reinterpreted as such only in the presence of a corrective statement that usually follows the negative sentence. ${ }^{8}$ These statements are what Horn calls garden-path utterances and their function is to clarify the reason why the speaker rejects a certain fact by means of metalinguistic negation. This means that most cases of metalinguistic negation are only interpreted as such after the garden-path utterance is produced. If no garden-path utterance is present (or somehow understood), then the negative sentence will be interpreted as regular negation.

In (24), the presence of the NPI is incompatible with the interpretation of the sentence as metalinguistic negation, which becomes clear after the garden-path utterance is introduced. Since in this case the negative sentence does not express regular negation, it does not trigger negative concord and, therefore, it does not legitimate the presence of the NPI.

8. This does not apply when we have unambiguous metalinguistic negation markers. 
$\begin{array}{llllllllll}\text { (24) } & \text { \# Este } & \text { filme } & \text { náo } & \text { vale } & \text { um } & \text { caraças. } & E & \text { melhor } & \text { filme } \\ \text { this } & \text { film } & \text { NEG } & \text { is.worth } & \text { a. }_{\text {MASC.SG }} & \text { CARAÇAS. } & \text { Is the } & \text { best } & \text { film } \\ \text { de } & \text { sempre. } & & & & & & \\ \text { of } & \text { always } & & & & & \end{array}$

'This film is not worth a thing. It is the best film ever.'

On the other hand, PPIs are allowed in metalinguistic negation contexts such as (25), precisely because we are not in the presence of regular negation (which would be incompatible with PPIs).

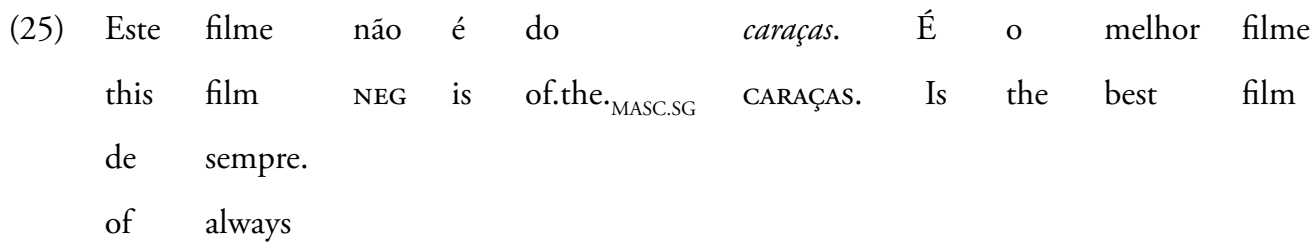

'This film is not awesome. It is the best film ever.'

We have seen so far that, not only caraças is not a single element with mixed behaviour, falling under the category of van der Wouden (1997)'s bipolar elements, but also that both the PPI (d)o caraças and the NPI um caraças assume rigid forms?.

As expected, the NPI can only occur in negative and modal contexts, being ruled out from affirmative assertive sentences. It is always an indefinite DP that seems to occur with most verbs. Differently, the PPI is licensed in affirmative assertive and modal contexts but it cannot occur in the scope of negation. It assumes the form of a definite DP, but it must be the complement of a PP introduced by the preposition $d e$ 'of'. The only exception is when it occurs in comparative sentences with como 'as' (apparently a comparative of equality), as in (26). It can appear with adjectives, as in (26), but also with a verbal form (27) or, eventually, with a noun $(28)^{10}$.

9. An anonymous reviewer argues in favour of a polyssemic status of the item caraças. I consider that all the uses described for caraças are built upon the common noun and emerge due to its strong emphatic meaning. Nevertheless, both the NPI and the PPI are syntactically independent items and seem to function as indivisible units (it is not possible to insert lexical material such as an adjective between the two units forming the NPI um caraças, as in *um só caraças)

10. Data from corpora shows a use of caraças that seems to correspond to a PPI but assuming a bare form and selected by a PP introduced by the preposition para 'for', as in (i):

\begin{tabular}{llll} 
(i) É & lento & pra & caraças. \\
Is & slow & for & CARAÇAS \\
'It is as slow as hell' & & \\
& \multicolumn{3}{c}{ Corpus do Português } \\
\end{tabular}


$\begin{array}{llllll}\text { (26) Ele fala } & \text { alto } & \text { como } & \text { caraças. } \\ \text { he talks loud } & \text { as } & \text { the. }{ }_{\text {MASC.SG }} & \text { CARAÇAS }\end{array}$

'He talks as loud as hell'

$\begin{array}{llll}\text { Choveu como o } & \text { caraças, ontem. } \\ \text { Rained. }{ }_{3 S G} \text { as the. }{ }_{\text {MASC.SG }} & \text { CARAÇAS } & \text { yesterday } \\ \text { 'It rained as hell, yesterday.' } & \end{array}$
(28) Vi pessoas como o caraças na rua. Saw. $_{1 S G}$ people as the. ${ }_{\text {MASC.SG CARAÇAS in.the street }}$
'I saw a hell of people in the street.'

The PPI also presents a much stricter group of contexts in which it may appear. Excluding comparative sentences like (26) to (28), its use is circumscribed to predicative contexts, mainly with verbs ser and estar 'to be'11 (29) or directly modifying a $\mathrm{DP}$ as in (30). The DP can be indefinite as in (30), definite as in (31), or assume the form of a bare noun as illustrated in (32).

$\begin{array}{llll}\text { (29) Este bolo é/está do } & \text { caraças. } \\ \text { this cake is } & \text { of.the. }{ }_{\text {MASC.SG }} & \text { CARAÇAS }\end{array}$

'This cake is awesome.'

$\begin{array}{lllllll}\text { (30) } & \text { P } & \text { Pedro tem } & \text { uma força do } & \text { caraças. } \\ \text { the } & \text { Pedro has } & \text { a } & \text { strength of.the CARAÇAS }\end{array}$

'Pedro is fucking strong.'

$\begin{array}{llllllll}\text { (31) Vê } & \text { a } & \text { sorte do } & \text { caraças que } & \text { Rui teve! } \\ & \text { See. }_{2 S G . I M P} & \text { the luck of.the. }{ }_{\text {MASC.SG }} & \text { CARAÇAS that the Rui had }\end{array}$

'Look at the hell of a luck Rui had!'

(32) Há dias do caraças!

there.are days of.the. ${ }_{\text {MASC.SG CARAÇAS }}$

'There are awesome days.'

11. It can also occur with other predicate verbs such as parecer 'to seem', ficar 'to remain'. 


\section{Other uses of caraças}

Caraças is a very productive item in colloquial oral speech ${ }^{12}$. As we have seen in the previous sections, it can still occur as a common noun and it is used both as a PPI maximizer and a NPI minimizer. Despite these contexts, caraças can also be found occurring with other independent uses, such as that of a metalinguistic negation marker, under the form of the definite DP o caraças. I have previously introduced the notion of metalinguistic negation to test the possibility of the NPI um caraças and the PPI (d)o caraças appear in such contexts. Here I will focus on the use of caraças as an unambiguous metalinguistic negation marker, comparing it to other similar markers available in EP.

The term metalinguistic negation was used by Horn (1989) to refer to contexts as the one illustrated in (33), in which the negative sentence does not imply the falsity of the fact under statement but is related to the assertability of the utterance.

(33) I didn't manage to trap two mongeese - I managed to trap two mongooses.

(Horn 1989: 371)

In Horn's own words, metalinguistic negation is

a device for objecting to a previous utterance on any grounds whatever, including the conventional or conversational implicata it potentially induces, its morphology, its style or register, or its phonetic realization.

(Horn 1989: 377)

In EP, metalinguistic negation can be conveyed by sentences equivalent to the one in (33), as shown in (34), but EP also exhibits unambiguous metalinguistic negation markers.

$\begin{array}{llllll}\text { (34) Eles não têm três filhos. Têm } & \text { quatro! } \\ \text { they } & \text { NEG have three sons } \text { Have. } 3 \mathrm{PL}_{\text {four }}\end{array}$

'They do not have three kids. They have four!'

12. Blogs and personal websites are said to present an informal register similar to colloquial oral speech. It is not surprising, therefore, that caraças is frequent in this type of source and its occurrence is registered in all the contexts described in this paper. A search in the Web/Dialects subpart of Corpus do Português returns 1875 occurrences of caraças, most of which do not correspond to the original nominal use. 
One of the features proposed by Horn (1989) to distinguish regular negation from metalinguistic negation is related to its compatibility with PPIs and NPIs. As we have seen in the previous section, metalinguistic negation is compatible with PPIs but does not legitimate NPIs, since it does not trigger negative concord. In (35) and (36) I illustrate the occurrence of the metalinguistic negation marker $o$ caraças with the PPI dos diabos (lit. 'of the devils') and the NPI nem morta (lit. 'not even dead'), respectively.

$\begin{array}{lllllll}\text { (35) A: } & \text { O paciente teve uma sorte } & \text { dos } & \text { diabos. } \\ & \text { the patient } & \text { had } & \text { a } & \text { luck } & \text { of.the devils }\end{array}$

A: 'The patient had a hell of a luck.'

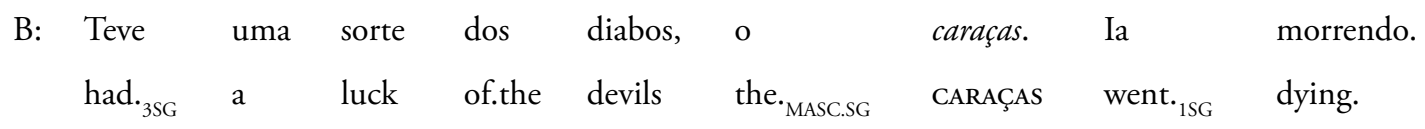

B: He had a hell of a luck, my butt. He almost died.

$\begin{array}{llll}\text { (36) A: } & \text { Hoje } & \text { cozinhas } & \text { tu! } \\ & \text { today } & \text { cook } & \text { you! }\end{array}$

A: 'You're cooking today!'

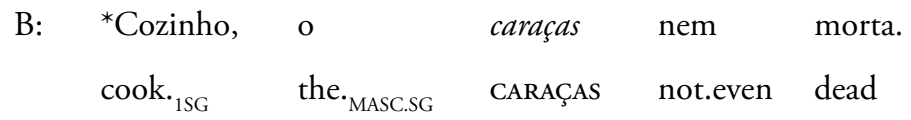

B:'The hell I'm cooking, not even dead'

As expected, o caraças is compatible with the PPI dos diabos in (35) but not with the NPI nem morta in (36). It also requests the presence of a previous discursive background to which the speakers can object to.

According to Martins $(2010,2012)$ metalinguistic negation markers can be internal, such as lá (lit. 'there') and $c a ́$ (lit. 'here'), or peripheral, as agora (lit. 'now') and nada (lit. 'nothing') (for this last one see Pinto 2010). In the group of peripheral markers we also find idiomatic expressions such as uma ova (lit. 'a fish egg'). I will try to show that caraças behaves as a peripheral idiomatic metalinguistic negation marker.

A characteristic feature of peripheral metalinguistic negation markers is that they can co-occur with regular negation in the same sentence. As example (37) illustrates, $o$ caraças behaves as a peripheral idiomatic metalinguistic negation marker in respect to this point, having scope over the negative sentence. 
(37)

\begin{tabular}{|c|c|c|c|c|c|c|c|c|}
\hline «Tom, & não & esquente» & & & & & & \\
\hline Tom & NEG & heat & & & & & & \\
\hline «Não & esquento, & o & caraças! & Não & saio & daqui & sem & saber. \\
\hline NEG & heat. $_{1 S G}$ & the. ${ }_{\text {MASC.SG }}$ & CARAÇAS & NEG & leave. $_{1 S G}$ & of.here & $\begin{array}{l}\text { with- } \\
\text { out }\end{array}$ & know \\
\hline
\end{tabular}

'Don't overreact, my butt! I will not leave here without knowing.'

A similar context with internal markers would be ruled out, as illustrated by example (38), where the negative sentence can only be rejected by means of a peripheral marker such as o caraças or uma ova, but not with lálcá.

$\begin{array}{lllll}\text { (38) A: } & \text { Nunca } & \text { mais } & \text { faltei } & \text { aulas. } \\ & \text { never } & \text { more } \text { missed. }_{15 \mathrm{SG}} \text { to.the classes. }\end{array}$

A: 'I never missed classes again.'

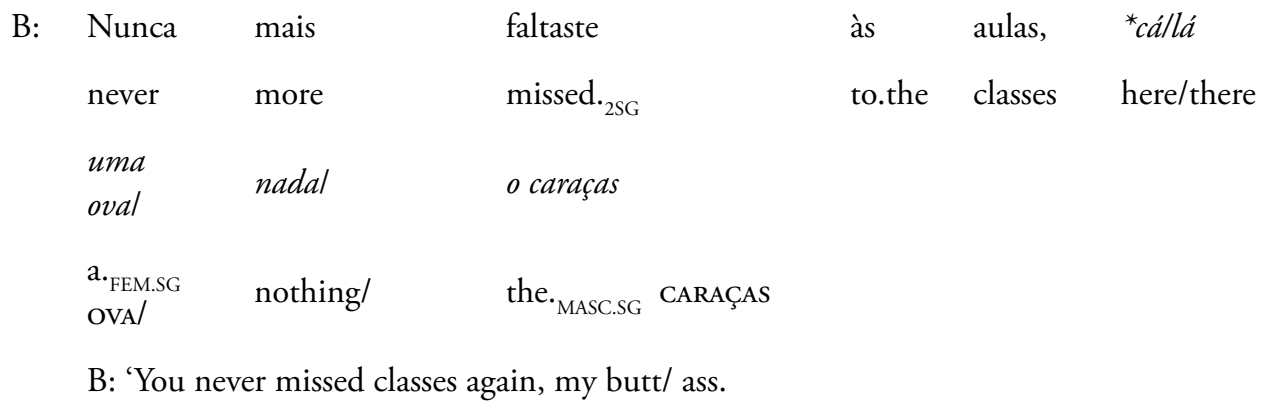

The marker $o$ caraças is also compatible with the emphatic adverb sempre ('always') (cf. Gonzaga 1997), just as verified for other peripheral markers (cf. Pinto 2010), but contrary to what happens with internal markers. Please observe examples (38) and (39), which illustrate both phenomena.

$\begin{array}{llll}\text { (39) A: } & \text { Afinal sempre choveu. } & \\ & \text { after.all always } & \text { rained }\end{array}$

A: 'It did rain after all.'

B: Sempre choveu, *cállá uma oval nadal o caraças

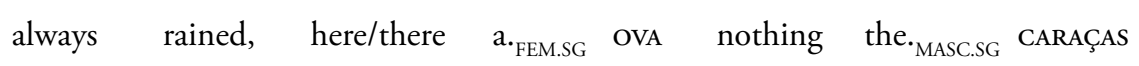
B: 'It did rain after all, my butt/ ass. 
Furthermore, peripheral markers are said to be able to occur alone or with nominal fragments, contrary to internal markers which return ungrammatical results in these contexts (cf. Martins 2012). Examples below show that 0 caraças presents similar behavior to the peripheral markers uma ova and nada, but differently from the internal ones cállá, being able to occur both with nominal fragments (40) and alone (41).

\begin{tabular}{|c|c|c|c|c|c|c|c|}
\hline (40) É & que & embirrou & que & queria & ter & o & vidro \\
\hline is & that & picked & that & wanted & to.have & the & window \\
\hline aberto & fresh & air - & dizia! & Fresh & air & o & caraças \\
\hline open & fresh & air - & said & fresh & air & $\begin{array}{l}\text { the.MASC. } \\
\text { SG }\end{array}$ & CARAÇAS \\
\hline
\end{tabular}

'The thing is that (s)he insisted (s)he wanted the window open - fresh air - (s)he said! Fresh air, my butt/ass.

(Corpus do Português: Web/Dialects)

$\begin{array}{lllllllll}\text { (41) Ah } & \text { e } & \text { tal } & \text { mas } & \text { é } & \text { táo } & \text { bom } & \text { sentir } & \text { o } \\ \text { Oh } & \text { and } & \text { so } & \text { but } & \text { is } & \text { so } & \text { good } & \text { feel } & \text { the } \\ \text { frio(?) } & \text { e } & \text { usar } & \text { cachecóis } & \text { quentinhos(?) } & \text { e } & \text { a } & \text { lareira } & \text { acesa(?) } \\ \text { cold } & \text { and } & \text { wear } & \text { scarfs } & \text { warm } & \text { and } & \text { the } & \text { fireplace } & \text { burning } \\ \text { e } & \text { o frio (?) } & \text { e } & \text { nhénhénhé. } & \text { O } & \text { caraças! } & \\ \text { and } & \text { the cold } & \text { and } & \text { bla bla bla } & \text { the.MASC. } & \text { CARAçAs }\end{array}$

'Oh, and come on, it is so nice to feel the cold and wear warm scarfs and the fireplace burning and the cold and bla bla bla. My butt/ass!

(Corpus do Português: Web/Dialects)

From the examples above we can conclude that $o$ caraças is a metalinguistic negation marker in EP, belonging to the set of peripheral markers. It is, nevertheless, associated to a very colloquial register and metalinguistic negation involving $o$ caraças may be considered rude and offensive.

Under the form of a definite DP, caraças is also used as what is usually referred in the literature as a $\mathrm{N}$-of-an- $\mathrm{N}$ construction ${ }^{13}$ (cf. Kayne 1994; Bennis et al. 1998). This use is illustrated in (42):

13. In Brito (2003), these constructions are referred to as qualitative expressions. 
$\begin{array}{llllllll}\text { (42) } \mathrm{O} & \text { mecânico } & \text { não } & \text { arranjou } & \mathrm{o} & \text { caraças } & \text { do } & \text { carro. } \\ \text { the } & \text { mechanic } & \text { NEG } & \text { fixed } & \text { the. } \text {.MASC.SG }_{\text {CARAçAS }} & \text { of.the } & \text { car }\end{array}$

'The mechanic did not fix the fucking car.'

$\mathrm{N}$-of-an-N constructions are composed by a sequence of a Noun followed by a preposition (in some languages the preposition does not exist) and a second Noun.

Among the main features of this construction are the fact that the first Noun cannot be set apart from the rest of the construction (that is to say, the PP), as illustrated in (43). Additionally, it is never the real direct object of the sentence, as highlighted in (44a). Only the second noun of the sequence can be interpreted as the DO, fulfilling the selection criteria imposed by the verb, as in (44b).

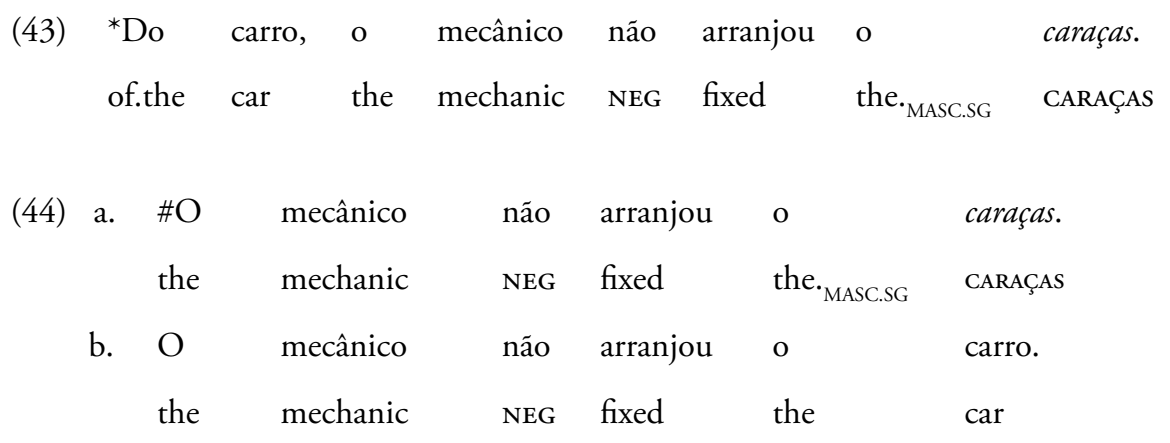

For these (and many other) reasons, the first Noun is considered to be semi-functional. The nature of the nouns participating in the construction, as well as its internal structure are ongoing topics of research, but outscope the purpose of this paper (see Alexiadou et al. 2007 and references therein for an overall discussion). Nevertheless, what I want to highlight here is the fact that, according to Matushansky (2001), the nouns that appear before the preposition are scalar. This means that caraças exhibits scalar properties in other uses beyond those as PPI and NPI.

Finally, caraças can also appear as an interjection in exclamations ${ }^{14}$, appearing in its bare form (45), as a definite DP (46) or an indefinite DP $(47)^{15}$ :

14. Caraças seems to be very productive in this particular context, although I lack statistical data to confirm this intuition. A statistical analysis of the distribution of caraças in its several contexts of occurrence is a topic worth future work.

15. An anonymous reviewer calls attention to the occurrence of caraças in exclamations, associated to a wh-element, as in (i). 


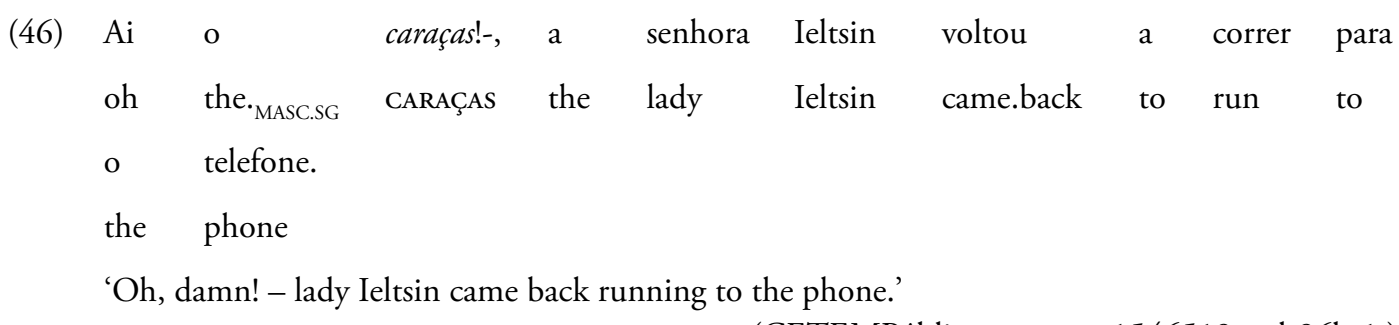

(CETEMPúblico - par=ext1546519-pol-96b-1:)

$\begin{array}{lllllll}\text { (47) C' } & \text { um } & \text { caraças! Aquela explosão foi } & \text { enorme! } \\ \text { with } & { }^{a} \cdot{ }_{\text {MASC.SG }} & \text { CARAÇAS that } & \text { explosion } & \text { was huge }\end{array}$

'Holly crap! That explosion was huge!'

In all the examples, the use of caraças is highly expressive and conveys surprise, fright or shock regarding a certain unexpected event, such as in (47), or it may express the dislike of the speaker when facing a particular unpleasant situation, as in (45) and (46).

\section{The origin of the non-nominal uses of caraças}

It is usually assumed that the great majority of minimizers and maximizers originate from a common noun with relevant semantic/scalar interpretation. In the case of maximizers, the common noun usually refers to something of great size or importance, while in the case of minimizers it refers to things of little size or value. The common noun would progressively loose its nominal properties until it grammaticalized into a (semi)-functional item. Given the existence of a common noun with the form caraça, we might expect to find an evolution path from the common noun to a polarity item, but that does not seem to be the case, since there was never a semantic relation between both uses to start with. The semantics associated to the noun caraça does not seem to directly or indirectly relate to neither the PPI interpretation nor the NPI interpretation.

\begin{tabular}{|c|c|c|c|c|c|c|c|}
\hline \multirow[t]{4}{*}{ (i) } & estou & há & duas & horas & $\mathrm{a}$ & tentar & descodificar \\
\hline & (I) am. $1 \mathrm{sg}$ & there.is & two & hours & to & try & decode \\
\hline & o & que & caraças & são & as & SWAPS & \\
\hline & the & what & CARAÇAS & are. ${ }^{3 \mathrm{pl}}$ & the & SWAPS & \\
\hline
\end{tabular}

'I have spent the last two hours figuring out what the hell are SWAPS.

(Corpus do Português: Web/Dialects)

Wh-elements may establish a close relation to degree expression, particularly in their ability to encode discursive values (cf. Dikken \& Giannakidou 2002; and also Amaral 2009 for Portuguese data) 
In this section I claim that the several uses of the form caraças are actually only orthographically related to the common noun caraça. The form caraças, in its multiple uses, has emerged as a very colloquial term in replacement of a taboo term considered extremely offensive - the swear word caralho 'dick' - which is frequently used as an intensifier.

According to Rhee (2016), intensifiers "share the function of marking the speaker's stance of emphasis" and they are related to degree expression (cf. Quirk et al. 1985). Taboo/swear words are considered productive sources of intensifiers, according to Napoli and Hoeksema (2009), and they may correspond to lexical items which only receive such interpretation when they are not used with their literal meaning, or they may be interpreted as taboo words at all times. That is the case of the root 'fuck', as Napoli and Hoeksema (2009) point out, which is a taboo at all times, as can be illustrated with sentences (48) and (49):

(48) I don't give a fuck.

(49) This is fucking awesome.

Both expressions - a fuck and fucking - are taboo terms that clearly serve as intensifiers, one intensifies negation in (48), and the other intensifies the positive degree of the adjective awesome in (49). Taboo and swear words are usually linked to specific lexical areas. Napoli and Hoeksema (2009) identify four main sources: religion, health, sex and bodily excretions. Due to their social inadequacy and offensive nature, a great number of these items developed euphemistic variants, socially more acceptable. That is the case of examples in (50) and (51) which illustrate the replacement of a term considered taboo for another socially more acceptable.

(50) doodly-squat $(\mathrm{EN})<$ doodly-shit

(51) blooming < bloody < blessed

(Vachek 1990: 29)

According to Vachek (1990), the adjective blessed had itself been a replacement of another offensive term and was latter replaced by bloody and then again by blooming. In other cases, the taboo terms are phonologically changed, constituting what Napoli and Hoeksema (2009) call 'phonological tamperings'. This strategy may consist of vowel change (as in shit > shoot), consonant changes (as in fuck > fugde) or insertion of a polite $<\mathrm{r}>$ in addition to consonant change (as in damn $>$ darn).

Parallel to the aforementioned examples, I argue that the item caraças is a replacement of the taboo and swear word caralho, a term considered highly offensive and obscene which designates the masculine sexual organ. Although its origin is uncertain (cf. Machado 1967, a.o. for etymological explanations), the word caralho is found 
very early in the language and already with a vulgar and obscene interpretation. One of the earliest attestations of caralho is found in Galician-Portuguese Medieval Songs, as the one illustrated in (52).

\begin{tabular}{|c|c|c|c|c|c|c|c|c|}
\hline (52) E & nun & caralho & grande & que & comprou, & loonte & ao & serã $[o]$ \\
\hline and & in.a & dick & big & that & bought & yesterday & in.the & evening \\
\hline esfolou, & le & outra & pissa & ten & ja & amormada. & & \\
\hline skinned & and & other & dick & has & already & sick & & \\
\hline
\end{tabular}

(TMILG, song by Pero Garcia Burgalês)

The example in (52) is extracted from a satirical song by Pero Garcia Burgalês concerning a woman named Maria Negra. It is considered one of the most obscene songs and it was written during the 13th century. The word caralho appears directly referring to the masculine sexual organ but with a very rude connotation that is maintained until nowadays.

The term caraças presents itself as a good candidate to be a more acceptable replacement of the offensive term caralho since it shares the same initial syllabic sequence cara-. Other terms also usually found as replacements for caralho are carago, which also shares the same syllabic beginning cara-, but also cacete, which only shares the first syllable. The term caralho is associated to slang and its use is socially reprehensible. Nevertheless, it is highly expressive and occurs in all the contexts described before for caraças. Examples from (53) to (57) bellow illustrate the occurrence of caralho and caraças in the exact same contexts with equivalent meaning, but with caraças being less offensive ${ }^{16}$.

$\begin{array}{lllllll}\text { Esta } & \text { noite } & \text { não } & \text { dormi } & \text { um } & \text { caraças } & \text { / caralho. } \\ \text { this } & \text { night } & \text { NEG } & \text { sleep } & a_{\text {MASC.SG }} & \text { CARAÇAS } & \text { /dick. }\end{array}$

'I did not sleep a fuck tonight.'

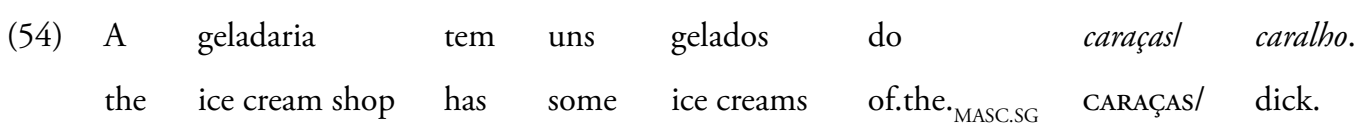
'The ice cream shop has some hell of an ice cream.'

16. The status of caraças as a swear word varies according to the speakers. For sake of simplicity I have used the same translation for both terms, but in an example such as (55), caraças probably corresponds to the English my butt and caralho to my ass. Similarly, in (57) caraças would correspond to crap and caralho to shit. 
$\begin{array}{cccccccc}\text { (55) A Podemos dar } & \text { ao } & \text { Rui } & \text { uma } & \text { viagem a } & \text { Paris. } \\ \text { Can } & \text { give to.the Rui } & \text { a } & \text { trip } & \text { to } & \text { Paris }\end{array}$

A:' We can offer Rui a trip to Paris.'

\begin{tabular}{|c|c|c|c|c|c|c|c|}
\hline B: Viagem & a & Paris & o & caraças/ & caralho. & Sabes & quanto \\
\hline trip & to & Paris & the. ${ }_{\text {MASC.SG }}$ & CARAÇAS/ & dick & know. $_{2 S G}$ & how.much \\
\hline isso & custa & & & & & & \\
\hline that & costs? & & & & & & \\
\hline
\end{tabular}

$\begin{array}{lllllllll}\text { (56) } \mathrm{O} & \text { caraçasl } & \text { caralho do cáo } & \text { ainda náo } & \text { parou } & \text { de } & \text { ladrar. } \\ \text { The. }{ }_{\text {MASC.SG }} \text { CARAÇAS/ dick } & \text { of.the } \operatorname{dog} \text { yet } & \text { NEG } & \text { stopped of } & \text { bark. }\end{array}$ 'The fucking dog has not stopped barking yet.'

$\begin{array}{llllllll}\text { (57) C’ } & \text { um } & \text { caraças/ caralho! Isso é que foi sorte! } \\ \text { with } & { }^{a}{ }_{\text {MASC.SG }} & \text { CARAÇAS/ dick } & \text { That is that was luck! }\end{array}$

Holly crap! That is what I call luck!

As we can see, both items can occur as PPIs, NPIs, metalinguistic negation markers, in N-of-an- $\mathrm{N}$ structures and interjections. In any of the cases, the use of both items is clearly a marked strategy to highlight the speaker's point of view concerning a given situation. It can be used to strongly express likes, dislikes or beliefs, by means of degree intensification

All the contexts of occurrence described for caraças/caralho correspond to the uses described by Napoli and Hoeksema (2009) for taboo terms and swear words and they may serve as an argument in favor of the enormous versatility of these linguistic items, which have received very little attention in the literature.

\section{Conclusion}

In this article I have investigated the existence of an item caraças in EP which is independent from the common noun caraça meaning mask. I have come to the conclusion that caraças appears associated to different constructions. It is part of the PPI (d)o caraças and the NPI um caraças, but it also occurs as a metalinguistic negation marker, under the form $o$ caraças. It participates in $\mathrm{N}$-of-an- $\mathrm{N}$ constructions and in exclamations. All these contexts are somewhat related to its scalar properties and to the strong emphatic value associated to it, probably due to its taboo-like status. It oc- 
curs mainly in pragmatic contexts expressing the speaker's evaluative point of view (as a PPI, NPI, a metalinguistic negation marker, but also in $\mathrm{N}$-of-an- $\mathrm{N}$ constructions and exclamations).

The idea that polarity items may be sensitive to a kind of scalar inferencing and not necessarily to negation itself was put forth by Israel (2001) while drawing a parallelism between polarity items and quantification properties of superlative constructions. Data presented here suggests that, along with scalarity, caraças's emphatic force (which is largely given by its offensive interpretation) may be responsible for its occurrence in multiple contexts, all of them involving the expression of the speaker's point of view. This is a topic that deserves being deepened in future work.

I have also proposed that the emergence of caraças in all the mentioned contexts was motivated by a need to replace a term considered offensive and socially inadequate - caralho. This seems to be a frequent strategy in different languages and highlights the fact that taboo terms are extremely rich linguistic items that need further study from a more theoretical perspective.

\section{Acknowledgments}

This investigation has been funded by the Fundação para a Ciência e Tecnologia (FCT) under the PhD Grant SFRH/BD/108094/2015. 


\section{References}

Alexiadou, Artemis / Liliane Haegeman \& Melita Sravrou. 2007. Noun phrase in the generative perspective. Berlin: Mouton de Gruyter. https://doi.org/10.1515/9783110207491.51

Amaral, Diana. 2009. Algumas construçôes-WH em português europeu: periferia esquerda e fases. Lisboa: Faculdade de Letras da Universidade de Lisboa. (Dissertaçấo de mestrado).

Bennis, Hans / Norbert Corver \& Marcel den Dikken.1998. Predication in nominal phrases. The journal of comparative germanic linguistics 1(2), 85-117. https://doi.org/10.1023/A:1009780124314

Bosque, Ignacio. 1996. La polaridad modal. In Actas del Cuarto congreso de hispanistas de Asia. 7-14. Seúl: Asociación Asiática de Hispanistas.

Brito, Ana Maria. 2003. Categorias sintácticas. In Maria Helena Mira Mateus / Ana Maria Brito / Inês Duarte \& Isabel Hub Faria (orgs.), Gramática da lingua portuguesa. 5.a edn. 393-475. Caminho: Lisboa.

CETEMPúblico $=$ Santos Diana \& P. Rocha. 2001. Evaluating CETEMPúblico, a free resource for Portuguese. In Proceedings of the 39th Annual Meeting of the Association for Computational Linguistics. 442-449. http://www.linguateca.pt/CETEMPublico/. (20/07/2019 and 25/02/2020).

Centro de Estudos de Teatro, Teatro de autores portugueses do Séc. XVII - Base de dados textual [on-line]. http://www.cet-e-seiscentos.com/

Corpus do Português (Web/Dialects) = Davies, Mark. 2016. Corpus do português: Web/Dialects. https:// www.corpusdoportugues.org/web-dial/. (25/02/2020).

Dikken, Marcel den \& Anastasia Giannakidou. 2002. From hell to polarity: 'Agressively non-D-linked wh-phrases' as polarity items. Linguistic Inquiry 33, 31-61. https://doi. org/10.1162/002438902317382170

Ferreira, Aurélio Buarque de Hollanda. 1986. Novo dicionário Aurélio da língua portuguesa. Rio de Janeiro: Nova Fronteira. (2a edição).

Giannakidou, Anastasia. 2011. Positive polarity items and negative polarity items: variation, licensing, and compositionality. I C. Maienborn / K. von Heusinger \& P. Portner (eds.), Semantics. An international handbook of natural language meaning. 1660-1712. Berlin: Mouton de Gruyter.

Gonzaga, Manuela. 1997. Aspectos da sintaxe do advérbio em português. Lisboa: Faculdade de Letras da Universidade de Lisboa. (Dissertaçấo de Mestrado).

Hoeksema, Jack. 2001. Rapid change among expletive polarity items. In Laurel J. Brinton (ed.), Selected Papers from 14th International Conference on Historical Linguistics. Vancouver. 9-13 August 1999. 175-186. Amsterdam/Philadelphia: John Benjamins. https://doi.org/10.1075/ cilt.215.13hoe

Horn, Laurence. 1989. A natural history of negation. Chicago: University of Chicago Press. (2001 reissue; Stanford: CSLI Publications).

Houaiss, Antônio \& Mauro de Salles Villar. 2002-2003. Dicionário Houaiss da lingua portuguesa. 6 vols. Lisboa: Círculo de Leitores.

Israel, Michael. 2001. Minimizers, maximizers, and the rhetoric of scalar reasoning. Journal of semantics 18, 297-331. https://doi.org/10.1093/jos/18.4.297

Kayne, Richard. 1994. The antisymmetry of syntax. Cambridge / Massachusetts: MIT Press. 
Machado, José Pedro. 1967. Dicionário etimológico da língua portuguesa. 2.a edn. Lisboa: Livros Horizonte.

Martins, Ana Maria. 2010. Negação metalinguística (lá, cá e agora). In Actas do XXV Encontro da APL. 67-587. Lisboa: APL.

Martins. Ana Maria. 2012. Deictic locatives, emphasis and metalinguistic negation. In Charlotte Galves / Sonia Cyrino / Ruth Lopes / Filomena Sandalo \& Juanito Avelar (eds.), Diachronic Syntax: Parameter Theory and Dynamics of Change. Oxford: Oxford University Press. https://doi. org/10.1093/acprof:oso/9780199659203.003.0012

Marquilhas, Rita (Coord.) P.S. Post-Scriptum: Arquivo digital de escrita quotidiana em Portugal e Espanha na Época Moderna. Centro de Linguística da Universidade de Lisboa. http://ps.clul.ul.pt/

Matushansky, Ora. 2001. Obligatory scalarity (a sliding scale). In K. Megerdoomian \& L. A. Bar-el (eds.), WCCFL 20 Proceedings, 400-413. Somerville, MA: Cascadilla Press.

Napoli, Donna Jo \& Jack Hoeksema. 2009. The grammatical versatility of taboo terms. Studies in language 33(3), 612-643. https://doi.org/10.1075/sl.33.3.04nap

Parry, Mair. 2013. Negation in the history of italo-romance. In D. Willis / Cristopher Lucas \& Anne Breitbarth (eds.), The history of negation in the languages of Europe and the Mediterranean. Vol I. 77-118. Case Studies, Oxford: Oxford University Press. https://doi.org/10.1093/acprof:oso/9780199602537.003.0003

Pinto, Clara. 2010. Negação metalinguística e estruturas com 'nada' em português europeu. Lisboa: Faculdade de Letras da Universidade de Lisboa. (Dissertação de mestrado).

Quirk, Randolph / Geoffrey Leech \& Sidney Greenbaum. 1985. A Comprehensive Grammar of the English Language. London / New York: Longman.

Rhee, Seongha. 2016. On the emergence of stance-marking function of English adverbs: A case of intensifiers. Linguistic Research 33(3), 395-436. https://doi.org/10.17250/khisli.33.3.201612.003

Santos, José Rodrigues dos. 2005. O Codex 632. Gradiva: Lisboa.

Spector, Benjamim. 2012. Being simultaneously an NPI and a PPI: a bipolar item in French. Snippets 25, 21-22. https://www.ledonline.it/snippets/allegati/snippets25008.pdf

TMILG = Varela Barreiro, Xavier (dir.). 2004-. Tesouro medieval informatizado da lingua galega. Santiago de Compostela: Instituto da Lingua Galega. http://ilg.usc.es/tmilg

Tubau, Susagna. 2016. On the syntax of english minimizers. Natural language and linguistic theory 34(2),739-760. https://doi.org/10.1007/s11049-015-9308-6

Twitter $=$ https://twitter.com/?lang=pt_pt

Vachek, J. 1990. A linguistic characterology of modern english. Praha: Státní pedagogické nakladatelství.

Willis, David. 2010. Motivating the emergence of new markers of sentential negation: the case of Welsh ddim. Diachronica 27(1), 110-156. https://doi.org/10.1075/dia.27.1.04wil

Willis, David. 2012. A minimalist approach to Jespersen's Cycle in Welsh. In Dianne Jonas / John Whitman \& Andrew Garrett (eds.), Grammatical change: Origins, natures, outcomes. 93-119. Oxford: Oxford University Press.

Wouden, Ton van der. 1997. Negative contexts. Collocation, polarity and multiple negation. London: Routledge. 